Ks. Paweł Wygralak ${ }^{1}$

\title{
Chrystus i Jego dzieło zbawcze w chrzcielnym nauczaniu Ildefonsa $z$ Toledo
}

\section{Wprowadzenie}

Ildefons z Toledo $(\dagger 667)$ w swoich dziełach na temat sakramentu chrztu świętego wiele miejsca poświęca osobie Jezusa Chrystusa. Przedstawienie prawowiernego nauczania na temat Zbawiciela było dla niego ogromnie ważne ze względu na konieczność dobrego teologicznego przygotowania duchownych, którzy mieli głosić katechezy dla katechumenów i neofitów. Mieli oni działać w społeczeństwie, w którym do niedawna oficjalnym wyznaniem wiary był arianizm. Wszak dopiero w czasie trzeciego synodu w Toledo (589) ogłoszono oficjalnie konwersję króla Wizygotów Rekkareda I $(† 601)$ na katolicyzm² ${ }^{2}$. Ponadto ciągle jeszcze można było spotkać wcale niemałe grupy ludzi oddających cześć bóstwom pogańskim i wszelkiego rodzaju formom idolatrii ${ }^{3}$. Stąd biskup Toledo starał się przedstawić argumenty na bóstwo Jezusa Chrystusa, omówić Jego dzieło zbawcze oraz ukazać rolę Zbawiciela w codziennym życiu człowieka ochrzczonego. Podstawą niniejszego artykułu stanowią dzieła Ildefonsa De cognitione baptismi oraz De itinere deserti, a także dostępna literatura przedmiotu, spośród której należy wspomnieć arty-

1 Ks. dr hab. Paweł Wygralak, prof. UAM, pracownik Wydziału Teologicznego Uniwersytetu im. Adama Mickiewicza w Poznaniu, e-mail: pawelwyg@amu.edu.pl, ORCID: 0000-0001-7790-7864.

2 Por. J. Orlandis, Historia de España. Epoca visigoda (409-711), Madrid 1987, 108-109.

3 Por. P. Wygralak, Stanowisko Kościoła wobec idolatrii i magii na terenach Galii i Hiszpanii w późnej starożytności chrześcijańskiej (VI-VII w.), Poznań 2011, 150-155. 
kuły autorstwa A. Martineza Sierra ${ }^{4}$ oraz monografię J.M. Hormaeche Basauriego ${ }^{5}$.

\section{Bóstwo Jezusa Chrystusa}

Już we wstępie do De cognitione baptismi Ildefons, podejmując się wyjaśnienia prawdy o pochodzeniu Kościoła, stwierdza, że „Ten, który dał początek stworzeniu anielskiemu, stał się dla ludzi Głową Kościoła"6. Jest On wcielonym Słowem Boga Ojca, Bogiem, który stworzył7. Przekonanie o prawdziwym bóstwie Jezusa Chrystusa wyraża autor dzieła wielokrotnie. Ta prawda jest bowiem dla każdego chrześcijanina fundamentalna, gdyż wyznanie wiary w Chrystusa prawdziwego Boga, Bożego Syna, daje gwarancję zbawienia ${ }^{8}$. Stwierdza więc dalej Ildefons, że ten Bóg, który jest ,jeden, niewidzialny, niepojęty, niedający się oszacować, nieśmiertelny, wszechmocny, doskonały i wieczny", , On jest Ojcem i Synem, i Duchem Świętym. W ten sposób, wymieniając przymioty Boga, biskup Toledo wskazuje wyraźnie na bóstwo zarówno Syna, jak i Ducha Świętego. Syn i Duch Święty posiadają tę samą naturę co Ojeiec ${ }^{10}$. Również odnosząc się do prawdy o zrodzeniu Syna, podkreśla, że jako zrodzony z Ojca jest także z Nim współwieczny, a zatem jest Bogiem ${ }^{11}$. Tę prawdę o zrodzeniu Syna powtórzy Ildefons jeszcze wiele razy, wyjaśniając poszczególne artykuły wyznania wiary. W tym przypadku, sięgając do słów psalmisty: „Z łona przed jutrzenką zrodziłem Ciebie" (Ps 110,3), wskazuje na fakt odwiecznego zrodzenia Syna przez Ojca ${ }^{12}$. Jest więc Syn zrodzony, a nie stworzony, co było tezą głoszoną przez wyznawców arianizmu. Syn, który jest mocą i mądrością, nie został zrodzony w czasie, gdyż Bóg Ojciec posiada moc

4 Por. A. Martínez Sierra, San Ildefonso de Toledo: fundamentos para una cristología, „Estudios Marianos” 74 (2008) 131-140.

5 Por. J.M. Hormaeche Basauri, La pastoral de la iniciación cristiana en la España visigoda: estudio sobre „De cognitione baptismi” de San Ildefonso de Toledo, Toledo 1983.

6 Ildefonsus Toletanus, De cognitione baptismi, Praefatio, CCL 114 A, 353, tt. A. Strzelecka, Ildefons z Toledo, Pouczenie o chrzcie, POK 33, Poznań 2018, 36.

7 Por. Ildefonsus Toletanus, De cognitione baptismi, Praefatio, CCL 114 A, 353.

8 Por. Ildefonsus Toletanus, De intinere deserti LXXXIX. Por. Martínez Sierra, San Ildefonso de Toledo, s. 137.

9 Ildefonsus Toletanus, De cognitione baptismi III, CCL 114 A, 354, POK 33, 39.

10 Por. F. Hidobro, San Ildefonso de Toledo, ,Teología y Vida” 23 (1982) 196.

11 Por. Ildefonsus Toletanus, De cognitione baptismi III.

12 Por. Ildefonsus Toletanus, De cognitione baptismi XXXVIII. 
i mądrość odwiecznie. Zatem ziemskie kategorie następstwa czasu nie mają w przypadku zrodzenia Syna przez Ojca zastosowania. Bóg zrodził Słowo, aby On, Boży Logos, objawił światu Ojca. Zatem człowiek może poznać Boga dzięki misji wcielonego Słowa. Przez Słowo „Bóg stworzył i ustanowił wszystko"13. Tenże Chrystus narodził się w ciele z Ducha Świętego i Maryi Dziewicy. Ildefons wyznaje jednoznacznie:

Słusznie wyznajemy tę prawdę, ponieważ Pan nasz, Jezus Chrystus, który jest Bogiem z Boga, narodził się z Ducha Świętego i Maryi Dziewicy. To znaczy, że począł się z obydwu substancji, mianowicie boskiej oraz ludzkiej, i jest jedynym Synem Boga Ojca Wszechmogącego, z którego pochodzi Duch Święty ${ }^{14}$.

Jest więc narodzony Zbawiciel w pełni Bogiem i w pełni człowiekiem. Wyraża tę prawdę Ildefons także w słowach: „ten sam Syn Boży jest Synem Człowieczym, a Syn Człowieczy jest Synem Bożym"15. Akcentując prawdę o bóstwie Jezusa Chrystusa, biskup Toledo wskazuje również na Jego prawdziwe człowieczeństwo, a jednocześnie na dziewictwo Maryi. Pisze bowiem, że Syn Boży w „łonie Dziewicy raczył przyjąć całego człowieka, czyli ciało, duszę i ducha, zamieszkując nienaruszone matczyne ciało i nienaruszone opuszczając"16. Podkreślenie, że Chrystus jest prawdziwym człowiekiem z ciałem, duszą i duchem, oraz wskazanie na dziewictwo Maryi jest precyzyjnym sformułowaniem prawowiernej nauki Kościoła. Ildefons wyraził te prawdy wiary, korzystając z całą pewnością z wypowiedzi św. Augustyna ${ }^{17}$. Być może więc i w wizygockiej Hiszpanii ciągle jeszcze można było spotkać się z błędnymi opiniami, negującymi nie tylko prawdziwe bóstwo Chrystusa, ale i Jego prawdziwe człowieczeństwo, a także prawdę o dziewictwie Maryi ${ }^{18}$. Hiszpański znawca twórczości Ildefonsa J.M. Hormaeche Basauri, odnosząc się do omawianego fragmentu De cognitione baptismi o dziewiczym poczęciu i dziewiczych narodzinach Chrystusa, stawia pytanie, czy w ten sposób biskup Toledo nie chce wskazać również na prawdę o niepokalanym poczęciu Najświętszej Maryi Panny. Uważa, że nie można wykluczyć takiej tezy, ale też nie można jej

13 Ildefonsus Toletanus, De cognitione baptismi XL, CCL 114 A, 376, POK 33, 74.

14 Ildefonsus Toletanus, De cognitione baptismi XLI, CCL 114 A, 377, POK 33, 75.

15 Ildefonsus Toletanus, De cognitione baptismi XLIII, CCL 114 A, 379, POK 33, 77.

16 Ildefonsus Toletanus, De cognitione baptismi XLIII. CCL 114 A, 379, POK 33, 78.

17 Por. Augustinus Hipponesis, De fide et symbolo 4, 8.

18 Należy wspomnieć tu o poglądach Apolinarego (zm. ok. 390), który głosił, że w Chrystusie miejsce duszy rozumnej zajął boski Logos. Zatem Chrystus nie był w pełni człowiekiem. Por. H. Pietras, Herezje, Kraków 2019, 73-77. 
przyjąć z całą pewnością ${ }^{19}$. Biskup Toledo, kontynuując temat wcielenia Bożego Syna, podkreśla, że chociaż w Credo wskazuje się, że w wydarzeniu tym wziął udział jedynie Duch Święty, to należy jednak pamiętać, iż we wszystkich wydarzeniach zbawczych działa zawsze „cała Trójca Święta, ponieważ dzieła Trójcy są nierozdzielne"20.

Według A. Martineza Sierry prawda o bóstwie Chrystusa została wyrażona przez Ildefonsa także wtedy, kiedy omawiając dzieło zbawcze Chrystusa, nazywa Go „wodzem dla odkupienia człowieka"21, a przede wszystkim gdy pisze o Chrystusie jako o sędziu żywych i umarłych, który zasiada po prawicy $\mathrm{Ojca}^{22}$. Zarówno bowiem odkupienie człowieka, jak i sąd nad światem i nad człowiekiem przysługują jedynie samemu Bogu ${ }^{23}$. Zatem w Chrystusie należy wyznawać prawdziwego Boga i prawdziwego człowieka.

\section{Dzieło zbawcze Chrystusa}

W odkupieniu człowieka uczestniczy cała Trójca Święta ${ }^{24}$. W opisie dzieła zbawczego Chrystusa Ildefons sięga do Pawłowej typologii o Chrystusie jako drugim Adamie (por. 1Kor 15,22) ${ }^{25}$. Chrystus jest zapowiedzianym potomkiem Dziewicy, który zmiażdży głowę wężowi. Zwycięstwo Chrystusa nad diabłem, zmiażdżenie głowy węża dokonuje się w chwili zmartwychwstania. Zdaniem biskupa Toledo prześladowcy Jezusa, którzy doprowadzili do śmierci Zbawiciela, to potomkowie węża. I w tym porównaniu należy widzieć nie tyle samego szatana, ile ludzi, którzy poddali się jego władzy. Głosem diabła nazywa z kolei biskup Toledo Piłata, którego język jest pokrętny i pełen kłamstwa. Jednocześnie bowiem rzymski namiestnik wydaje dwa wyroki: usprawiedliwia Jezusa i skazuje Go, zgadzając się na spełnienie woli Żydów ${ }^{26}$. Innym starotestamentalnym

19 Por. Hormaeche Basauri, La pastoral de la iniciación cristiana en la España visigoda, s. 66.

20 Ildefonsus Toletanus, De cognitione baptismi XLI, CCL 114 A, 377; 405, POK 33,76 .

21 Ildefonsus Toletanus, De cognitione baptismi CI, CCL 114 A, 405, POK 33, 119.

Por. Martinez Sierra, San Ildefonso de Toledo, s. 137.

22 Por. Ildefonsus Toletanus, De cognitione baptismi LII, LIII, CXLIII.

23 Por. Martinez Sierra, San Ildefonso de Toledo, s. 137.

24 Por. Ildefonsus Toletanus, De cognitione baptismi IX.

25 Por. Ildefonsus Toletanus, De cognitione baptismi VII. Por. Hormaeche Basauri, La pastoral de la iniciación cristiana en la España visigoda, s. 65.

26 Por. Ildefonsus Toletanus, De cognitione baptismi XLV. 
obrazem zapowiadającym śmierć Chrystusa była śmierć Abla. Kain jest typem ludu żydowskiego, który doprowadza do śmierci Zbawiciela, Bożego Baranka $^{27}$.

Chrystus, podejmując krzyżową mękę, najpełniej okazał bogactwo swego miłosierdzia wobec grzesznych ludzi. Wybór rodzaju śmierci wiązał się z wydarzeniami w raju. Tam przez drzewo człowiek odwrócił się od Boga, tutaj przez cierpienie Zbawiciela na drzewie krzyża człowiek odzyskuje szansę powrotu do Boga ${ }^{28}$. W ten sposób zostało też zwyciężone panowanie diabła, a dzięki przelaniu Krwi Chrystusa powstało Jego królestwo, które będzie trwało na wieki ${ }^{29}$. Według Ildefonsa dzięki tym zbawczym wydarzeniom nastał trzeci okres w dziejach świata. Pierwszym bowiem był czas spędzony przez człowieka $\mathrm{w}$ raju, a drugim - najgorszym w dziejach świata - czas panowania diabła ${ }^{30}$.

Chrystus, który, jak już wyżej wspomniano, jest zdaniem biskupa Toledo „wodzem dla odkupienia człowieka"31, przyjmując chrzest od Jana, ustanowił sakrament chrztu świętego ${ }^{32}$. Ildefons wyraźnie podkreśla, że chrzest jest sakramentem zbawienia (sacramentum redemptionis) ${ }^{33}$. Zbawcza moc wód chrztu świętego płynie z drzewa krzyża. Wyjaśniając tę prawdę, biskup Toledo, podobnie jak inni ojcowie ${ }^{34}$, sięga do wydarzeń opisanych w Księdze Wyjścia (Wj 14,16). Mojżesz wyciągnął swoją laskę nad wodami morza i w ten sposób otworzył uciekającemu z niewoli egipskiej ludowi Izraela drogę do wolności. I podobnie woda chrztu została dotknięta drzewem krzyża, stając się w ten sposób źródłem wyzwolenia $\mathrm{z}$ niewoli grzechu dla wszystkich ochrzczonych ${ }^{35}$. Zbawienie człowieka może się bowiem dokonać jedynie poprzez działania łaski Bożej ${ }^{36}$.

Ildefons zauważa, że Chrystus nie udzielał osobiście sakramentu chrztu, ale czynili to Jego uczniowie. Samo obmycie wodą nie byłoby jednak skuteczne, gdyby nie udział Chrystusa. To On bowiem jest Tym,

27 Por. Ildefonsus Toletanus, De cognitione baptismi VIII. Por. Martínez Sierra, San Ildefonso de Toledo, s. 136; Hormaeche Basauri, La pastoral de la iniciación cristiana en la España visigoda, s. 66.

28 Por. Ildefonsus Toletanus, De cognitione baptismi XLVI.

29 Por. Ildefonsus Toletanus, De itinere deserti II.

30 Por. Ildefonsus Toletanus, De itinere deserti II.

31 Ildefonsus Toletanus, De cognitione baptismi CI, CCL 114 A, 405, POK 33, 119.

32 Por. Ildefonsus Toletanus, De cognitione baptismi XIV.

33 Por. Ildefonsus Toletanus, De cognitione baptismi XII; Hormaeche Basauri, La pastoral de la iniciación cristiana en la España visigoda, s. 69.

34 Por. Caesarius Arelatensis, Sermo 97, 3.

35 Por. Ildefonsus Toletanus, De cognitione baptismi CXII.

36 Por. Ildefonsus Toletanus, De itinere deserti XIX. 
który oczyszcza przyjmującego chrzest człowieka z wszystkich grzechów. Te sformułowania potwierdzają wypowiedzi innych ojców ${ }^{37}$, zgodnie z którymi to Chrystus w sakramentach udziela swojej łaski. Człowiek natomiast pozostaje jedynie szafarzem sakramentów. Biskup Toledo wyraża tę zasadę $\mathrm{w}$ sposób, który nie pozostawia żadnych wątpliwości: „Moc sakramentu nie zależy bowiem od posługi szafarza, ale opiera się na władzy Mistrza" 38 . Ta prawda jest bardzo ważna dla praktyki sakramentalnej Kościoła, gdyż wyklucza konieczność powtórnego udzielania sakramentu chrztu, a więc praktyki stosowanej przez niektóre nieprawowierne wspólnoty chrześcijańskie ${ }^{39}$. Ildefons przekonywał czytelników swego dzieła:

Niech człowiek spokojnie podchodzi do ziemskiego szafarza, gdyż ma niebiańskiego Mistrza. Chrystus-Nauczyciel sam udziela bowiem chrztu zarówno zewnętrznie, zgodnie ze słowami Pawła: „Tak Chrystus umiłował Kościół i wydał za niego samego siebie, aby go oczyścić obmyciem wody"40, jak i wewnętrznie, przez wylanie Ducha, który będzie uczył duchowego człowieka posiadania wiary i zachowywania moralności w postępowaniu ${ }^{41}$.

A zatem każdy człowiek ma do sakramentów przystępować zawsze $\mathrm{z}$ wewnętrznym pokojem w przekonaniu, że ważność sakramentu nie jest zależna od postawy szafarza. Tym, który udziela łaski, jest bowiem sam Chrystus. Skutkiem przyjętego sakramentu chrztu świętego jest uwolnienie człowieka z grzechu. Gdy sakrament ten przyjmują dzieci, otrzymują odpuszczenie grzechu pierworodnego, gdy zaś wody chrztu spływają na osoby starsze, wówczas otrzymują również łaskę odpuszczenia grzechów osobistych, popełnionych w ciągu dotychczasowego życia. Biskup Toledo stwierdza przy okazji, że chrzest pozostaje warunkiem zbawienia: „Wszyscy bowiem, którzy odejdą do wieczności zanim odrodzili się przez chrzest, nie będą w królestwie Bożym dziedzicami Chrystusa, gdyż Pan powiada: «Jeśli się ktoś nie narodzi po-

37 Por. Augustinus Hipponensis, In Joannis Evangelium Tractatus V 1, 8.

38 Ildefonsus Toletanus, De cognitione baptismi XVI, CCL 114 A, 362, POK 33, 51. Por. Augustinus Hipponensis, In Joannis Evangelium Tractatus V 1, 8.

39 Powtórnego chrztu udzielali donatyści. O zależności ważności chrztu od godności szafarza był przekonany także św. Cyprian, biskup Kartaginy. Por. A. Żurek, Jeden chrzest w jednym i świętym Kościele - w poszukiwaniu istoty donatyzmu, w: Ortodoksja, herezja, schizma w Kościele starożytnym, red. F. Drączkowski - J. Pałucki - P. Szczur M. Szram - M. Wysocki - M. Ziółkowska, Lublin 2012, 123-131.

\footnotetext{
40 Ef 5,25-26.

41 Ildefonsus Toletanus, De cognitione baptismi XVI, CCL 114 A, 361, POK 33, 50.
} 
wtórnie z wody i Ducha Świętego, nie zobaczy królestwa Bożego»” (J $3,3)^{42}$.

W tym miejscu należy jednak zaznaczyć, że zdaniem autora dzieła, oprócz chrztu sakramentalnego, jako ważny należy uznać chrzest z krwi, a więc męczeńską śmierć osoby nieochrzczonej, która umiera za wiarę w Jezusa Chrystusa. Jako trzeci rodzaju chrztu uznanego przez tradycję Kościoła należy uznać chrzest z łez pokuty. Uzasadnienie tej tezy znajduje Ildefons w wydarzeniach opisanych zarówno w Starym, jak i w Nowym Testamencie: nawrócenie mieszkańców Niniwy (por. Jon 3), łzy psalmisty (por. Ps 6,7), żal grzesznej kobiety, która łzami obmywała stopy Jezusa (por. Łk 7,37-38.47) . $^{43}$

\section{Rola Chrystusa w życiu chrześcijanina}

Z chwilą przyjęcia sakramentu chrztu świętego przed człowiekiem otwiera się nowe życie. Sięgając do nauczania św. Pawła, Ildefons stwierdza:

Wszyscy ochrzczeni w Chrystusie Jezusie, zostaliśmy obmyci w Jego śmierci. Zostaliśmy wraz z Nim pogrzebani przez zanurzenie w [Jego] śmierci (Por. Rz 6,3-4). Wynurzenie chrzczonego z wody ukazuje natomiast, że zmartwychwstał w Chrystusie, zgodnie z przekazem tegoż Apostoła: „Abyśmy mogli wkroczyć w nowe życie, jak Chrystus powstał z martwych dzięki chwale Ojca" (Por. Rz 6,4)

Biskup Toledo był przekonany, że w nowym życiu ochrzczony cieszy się codzienną obecnością Chrystusa. Od tego momentu On jest tym, który przewodzi człowiekowi na drogach jego życia. Podobnie jak obłok wskazywał Izraelitom wędrującym do ziemi obiecanej kierunek drogi przez pustynię, tak i Chrystus, który zdaniem biskupa Toledo był tym obłokiem, wskazuje teraz kierunek drogi w życiu chrześcijanina. Na tej drodze nie tylko jest przewodnikiem, ale i przykładem. Jego życie stanowi bowiem dla wiernych

42 Ildefonsus Toletanus, De cognitione baptismi CXVI, CCL 114 A, 415, POK 33, 134.

43 Por. P. Wygralak, Przygotowanie do chrztu w Hiszpanii Wizygockiej. Wskazania Ildefonsa z Toledo (†667), w: Ildefons z Toledo, Pouczenie o chrzcie, POK 33, Poznań 2018, 28.

44 Ildefonsus Toletanus, De cognitione baptismi CXX, CCL 114 A, 416, POK 33, 137. Por. Ildefonsus Toletanus, De cognitione baptismi CXLIX. 
najlepszy wzór życia zgodnego z wolą Ojca ${ }^{45}$. Szczególną rolę odgrywa tu światło Ewangelii (lumen Evangelicum). To ono wskazuje uczniom Jezusa właściwe drogi postępowania ${ }^{46}$. Ponadto jak ów słup ognia stanął pomiędzy Egipcjanami a uciekającymi Izraelitami i dla jednych był zgubą, a dla drugich ucieczką, tak teraz Chrystus przychodzi do człowieka z uprzedzającą łaską i pragnie jego dobra, nawet jeśli on tego nie chce. W ten sposób Ildefons przekonuje o mocy uprzedzającej łaski Bożej. „Łaska Zbawiciela wyprzedza bowiem z miłością wolną wolę ludzką, aby człowiek pragnął postępować godziwie, i miłosiernie go wyposaża, aby mógł to czynić" ${ }^{47}$. Chrystus zatem nie tylko daje przykład, nie tylko wskazuje człowiekowi kierunek działania, ale nade wszystko, powodowany miłością, obdarza go uprzedzającą łaską, która ma moc wsparcia wolnej woli człowieka, aby wybrał drogę życia zgodną z zobowiązaniami przyjętymi w sakramencie chrztu świętego. Szczególnymi darami, które wyprasza dla człowieka Chrystus, są charyzmaty. Ildefons podkreśla, że te wyjątkowe dary, którymi obdarza Duch Święty, mają umocnić człowieka w jego drodze do wiecznej ojczyzny ${ }^{48}$.

Dzięki przyjętemu sakramentowi chrztu chrześcijanin zostaje obdarowany pokarmem na życie wieczne, którym jest Ciało i Krew Chrystusa. Biskup Toledo, wskazując na wartość Eucharystii, przywołuje wydarzenia z pobytu Izraelitów na pustyni. Pili oni wodę, która w cudowny sposób, uderzeniem laski, została przez Mojżesza wydobyta ze skały. Według Ildefonsa, który powołuje się na słowa św. Pawła (por. 1Kor 10,4), woda ta była tylko zapowiedzą prawdziwego duchowego napoju ${ }^{49}$. Jedynie prawdziwie duchowy napój bowiem wypłynął z boku ukrzyżowanego Chrystusa. Tylko ten pokarm daje życie wieczne i jest gwarancją zjednoczenia z Chrystusem. Zapewniał o tym sam Zbawiciel: „Kto spożywa moje Ciało i Krew moją pije, trwa w Mnie, a Ja w nim $(\mathrm{J} 6,56)^{50}$. Tej jedności Chrystusa i ochrzczonego człowieka pragnie sam Bóg Ojciec, co Ildefons wyraża słowami, aby „Chrystus, który jest chlebem życia i chlebem z nieba, codziennie w nas mieszkał" ${ }^{\circ 1}$.

\footnotetext{
45 Por. Ildefonsus Toletanus, De cognitione baptismi XCIX.

46 Por. Ildefonsus Toletanus, De itinere deserti XIII.

47 Ildefonsus Toletanus, De cognitione baptismi C, CCL 114 A, 405, POK 33, 119.
}

Por. Ildefonsus Toletanus, De itinere deserti LXXIV.

48 Por. Ildefonsus Toletanus, De itinere deserti XXIV.

49 Por. Ildefonsus Toletanus, De cognitione baptismi CXLII.

50 Ildefonsus Toletanus, De cognitione baptismi CXLII, CCL 114 A, 430, POK 3, 157. Por. Montealegre, El „Libro de conocimiento del santo Bautismo” de San Ildefonso de Toledo, „Toletana” 17 (2007) 138-139.

51 Ildefonsus Toletanus, De cognitione baptismi CXLI, CCL 114 A, 429, POK 33, 156. 
Ildefons był przekonany, że jedyną drogą do zbawienia jest zjednoczenie z Chrystusem. Inicjatorem tego zjednoczenia jest sam Zbawiciel. To On wychodzi naprzeciw człowiekowi i obdarza go swoją łaską. Biskup Toledo kończy więc De cognitione baptismi modlitwą, która jednocześnie zawiera jego życzenia dla wszystkich ochrzczonych. Życzy więc im, aby cieszyli się światłem Odkupiciela, dzięki któremu zostaną zachowani w doczesnym pielgrzymowaniu od wszelkiego zła i doprowadzeni do oczekującej ich przyszłej nagrody ${ }^{52}$. W ten sposób hiszpański biskup po raz kolejny wyraża swoje głębokie przekonanie, że tylko Chrystus może doprowadzić człowieka do radości życia wiecznego.

\section{Podsumowanie}

Ildefons z Toledo całe swoje nauczanie o Jezusie Chrystusie opiera na odpowiednio dobranych tekstach Pisma Świętego Starego i Nowego Testamentu, a także na tradycyjnej nauce Kościoła zawartej w nauczaniu wcześniejszych Ojców Kościoła. Zależy mu na ukazaniu ciągłości historii zbawienia, w której centralnymi wydarzeniami są wcielenie, śmierć i zmartwychwstanie Chrystusa. Jezus Chrystus, prawdziwy Bóg i prawdziwy człowiek, na drzewie krzyża zwyciężył szatana i otworzył człowiekowi drogę do nowego życia. To nowe życie otrzymuje człowiek w sakramencie chrztu. Wszystkich ochrzczonych obdarza Chrystus łaską uprzedzającą, która pozwala im prowadzić życie zgodne z wolą Bożą. Ponadto Zbawiciel oświeca człowiekowi drogę codziennego życia światłem Ewangelii, karmi Pokarmem na życie wieczne, obdarza niezbędnymi darami, a przede wszystkim sam daje przykład życia zgodnego z wolą Boga Ojca. W ten sposób jako prawdziwy Bóg i prawdziwy człowiek prowadzi ochrzczonych do ostatecznego celu, jakim jest życie wieczne.

\section{Chrystus i Jego dzieło zbawcze w chrzcielnym nauczaniu Ildefonsa z Toledo}

(streszczenie)

W artykule zostało omówione nauczanie Ildefonsa $\mathrm{z}$ Toledo na temat osoby Jezusa Chrystusa i Jego zbawczego dzieła. Podstawą przedstawionego opracowania były dwa dzieła biskupa Toledo (Do cognitione baptismi i De itinere deserti), w których zawarł on pouczenia dotyczące sakramentu chrztu. W chrzcie świętym każdy człowiek dzięki męce

52 Por. Ildefonsus Toletanus, De cognitione baptismi CXLIX. 
i zmartwychwstaniu Chrystusa otrzymuje nowe życie. Może je człowiekowi ofiarować jedynie sam Bóg. Ildefons podkreśla więc prawdę o bóstwie Jezusa Chrystusa, omawia Jego zbawcze dzieło i wskazuje na nieustanną obecność Chrystusa w życiu wszystkich ochrzczonych. Jezus Chrystus obdarza ochrzczonych swoją uprzedzającą łaską, wspiera ich wszelkimi potrzebnymi darami, daje im przykład życia zgodnego z wolą Boga Ojca. Wszystko to czyni po to, aby doprowadzić ich do radości życia wiecznego. Ildefons z Toledo opiera swoje nauczanie na Piśmie Świętym, odwołując się przede wszystkim do tekstów Starego Testamentu i nauczania św. Pawła.

Słowa klucze: Ildefons z Toledo; Jezus Chrystus; chrzest; zbawienie

\section{Christ and His Salvific Work in the Baptismal Preaching of St. Ildefonsus of Toledo}

(summary)

The article describes the teaching of Ildefonsus of Toledo on the person of Jesus Christ and his salvific work. The study is based on two writings of the Bishop of Toledo: De cognitione baptismi and De itinere deserti, in which he conveyed his instruction on the sacrament of baptism. In holy baptism each man, thanks to the passion and resurrection of Christ, receives new life. It can be given to man only by God Himself. Therefore, Ildefonsus emphasizes the truth of the divinty of Jesus Christ, discusses his salvific work and points to the continuing presence of Christ in the life of all the baptized. Jesus Christ grants his prevenient grace to all the baptized, supports them with all the necessary gifts, sets them an example of a life lived in accordance to the will of God the Father. He does all this to lead them to the joy of eternal life. Ildefonsus of Toledo bases his preaching on the Scripture, referring mostly to the texts of the Old Testament and the teaching of St. Paul.

Keywords: Ildefonsus of Toledo; Jesus Christ; baptism, salvation

\section{Bibliografia}

\section{Źródla}

Ildefonsus Toletanus, De cognitione baptismi, red. V. Yarza Urquiola, CCL 114 A, Turnhout 2007, 352-435, tł. A. Strzelecka, Ildefons z Toledo, Poznanie chrztu, POK 33 , Poznań 2018, 35-164.

Ildefonsus Toletanus, De itinere deserti, red. V. Yarza Urquiola, CCL 114 A, Turnhout 2007, 436-471.

\section{Opracowania}

Hidobro F., San Ildefonso de Toledo, Teología y Vida 23 (1982) 191-202. 
Hormaeche Basauri J.M., La pastoral de la iniciación cristiana en la España visigoda: estudio sobre „De cognitione baptismi” de San Ildefonso de Toledo, Toledo 1983.

Martínez Sierra A., San Ildefonso de Toledo: fundamentos para una cristología, Estudios Marianos 74 (2008) 131-140.

Montealegre C.S., El „Libro de conocimiento del santo Bautismo” de San Ildefonso de Toledo, Toletana 17 (2007) 103-142.

Orlandis J., Historia de España. Epoca visigoda (409-711), Madrid 1987.

Pietras H., Herezje, Kraków 2019.

Wygralak P., Stanowisko Kościoła wobec idolatrii i magii na ternach Galii i Hiszpanii w późnej starożytności chrześcijańskiej (VI-VII w.), Poznań 2011.

Wygralak P., Przygotowanie do chrztu w Hiszpanii Wizygockiej. Wskazania Ildefonsa z Toledo (†667), w: Ildefons z Toledo, Pouczenie o chrzcie, POK 33, Poznań 2018, 7-33.

Żurek A., Jeden chrzest w jednym i świętym Kościele - w poszukiwaniu istoty donatyzmu, w: Ortodoksja, herezja, schizma w Kościele starożytnym, red. F. Drączkowski - J. Pałucki - P. Szczur - M. Szram - M. Wysocki - M. Ziółkowska, Lublin 2012, 123-131. 
